\title{
Forty-seven years later: the blue crab Callinectes sapidus Rath- bun, 1896 (Crustacea Decapoda Portunidae) reappears in the Strait of Messina (Sicily, Italy)
}

\author{
Salvatore Giacobbe*, Medea Lo Piccolo \& Giuseppe Scaduto \\ Department of Chemical, Biological, Pharmaceutical and Environmental Sciences, University of Messina, Viale F. Sta- \\ gno d'Alcontres 31, 98166 Messina, Italy \\ ${ }^{*}$ Corresponding author, e-mail: sgiacobbe@unime.it
}

ABSTRACT

The second record of the invasive blue crab Callinectes sapidus Rathbun, 1896 (Crustacea Decapoda Portunidae) from the Strait of Messina has been reported, forty-seven years after the first record in this area. The specimen, a large-sized adult female, was collected in the Capo Peloro Lagoon, a natural reserve whose brackish waters represent a highly favorable environment for this euryhaline opportunistic species. The actual possibility that $C$. sapidus may settle in the Lagoon should be carefully evaluated, and a mitigation strategy, involving selective removal of pioneer specimens, timely envisaged.

KEY WORDS Crustaceans; Invasive species; Mediterranean; Brackish environments; Natural Reserves.

Received 16.10.2019; accepted 30.10.2019; published online 11.12.2019

\section{INTRODUCTION}

The American blue crab Callinectes sapidus Rathbun, 1896 (Crustacea Decapoda Portunidae), whose areal ranged from Canada to Argentina along the whole Atlantic western coasts (Nehring, 2011), in the early 20th century spread eastward, reaching the European coasts and, in order, North Sea, Mediterranean Sea, Baltic Sea, Black Sea and probably the Sea of Azov (Nehering, 2011, and references cited therein). All records, nevertheless, for over half a century were almost scattered, suggesting multiple independent introductions, with ballast water as the major introduction vector, without any success over time. The actual settlement of $C$. sapidus, which is now recognized as one of the worst invasive species in the Mediterranean Sea (Zenetos et al., 2005), has been thus dated back to the beginning of the 21 st century
(Galil et al., 2008), with first evidences of a still ongoing colonizing wave (Mancinelli et al., 2013; Karachle, 2013; Garcia et al., 2018; Piras et al., 2019). In Sicily, records of $C$. sapidus have been reported from the Strait of Messina (Cavaliere \& Berdar, 1975), eastern coasts of Sicily (Franceschini et al., 1993) and Strait of Sicily (Insacco \& Zava, 2017), but evidences on established populations in Sicilian waters are lacking.

\section{MATERIAL AND METHODS}

Brackish benthic communities in the Strait of Messina area have been monthly monitored since 2008, in the framework of the program: "Settlement dynamics and colonization of allochthonous assemblages in the Capo Peloro Lagoon". The lagoon is a Natural Reserve consisting of two differently fea- 
tured basins, Lake Faro and Lake Ganzirri, connected to each other and to the sea by canals (Fig. 1). The Lake Ganzirri $\left(38^{\circ} 15^{\prime} 38^{\prime \prime} \mathrm{N} ; 15^{\circ} 37^{\prime} 2^{\prime \prime} \mathrm{E}\right)$ is a microtidal coastal pond, covering a 34 ha area and reaching $7 \mathrm{~m}$ maximum depth. It is connected to the sea by the "Due Torri" canal, in the north, while in the south a minor canal, "Catuso", allows faint water exchange.

The monitoring, carried out by snorkelling and SCUBA diving from $0 \mathrm{~m}$ to $3 \mathrm{~m}$ depth in the lake Ganzirri and related canals, provided specimen collections and photo documentation, now available at the Benthic Ecology Laboratory, Messina University.

\section{RESULTS}

A blue crab specimen was found on 22 May 2019, during the normal monitoring activities carried out in the Peloro Lagoon. In particular, a not ovigerous female was photographed in vivo (Fig. 2) in the inlet of the "Due Torri" canal, on gravelly sand, 0.1 $m$ depth, during change of tide and full moon.

The crab specimen, handily collected, was identified in laboratory as $C$. sapidus, according to Williams (1974). It measured $74.8 \mathrm{~mm}$ in carapace length, $\mathrm{CL}$, and $184.0 \mathrm{~mm}$ in carapace width, $\mathrm{CW}$ (Width / Length ratio $=2.46$ ), corresponding to the largest size of adult females (Williams, 1974), as also observed in established Mediterranean populations (Türeli et al., 2016).

This basic measures and other morphometric parameters are synthesized in Table 1.

The living specimen dorsally displayed a grayish, bluish to brownish green color, with orange fingers on chelae tipped with purple, and under parts off-white with tints of yellow and pink, as characteristic of adult females. The specimen has been deposited as dried sample in the scientific collection of the Benthic Ecology Laboratory (ChiBioFarAm Department, Messina University), with reference code BEL135CRGANZ3Ce.

\section{DISCUSSION AND CONCLUSIONS}

The actual occurrence of $C$. sapidus in Sicilian waters, so far attested by occasional records, is questionable. Insacco \& Zava (2017), reporting the "First record of the Blue Crab Callinectes sapidus in Sicily", did not give credit to Franceschini et al. (1993) which cited C. sapidus for the Ionian coasts of Sicily, neither to Cavaliere \& Berdar (1975) which reported two female specimens from the Strait of Messina. Formerly, Galil et al. (2011), have considered unconfirmed the reports from the Ionian coasts, because lacking of details, but they credited the records from Messina, whose photos and synthetic description allow an unambiguous attribution

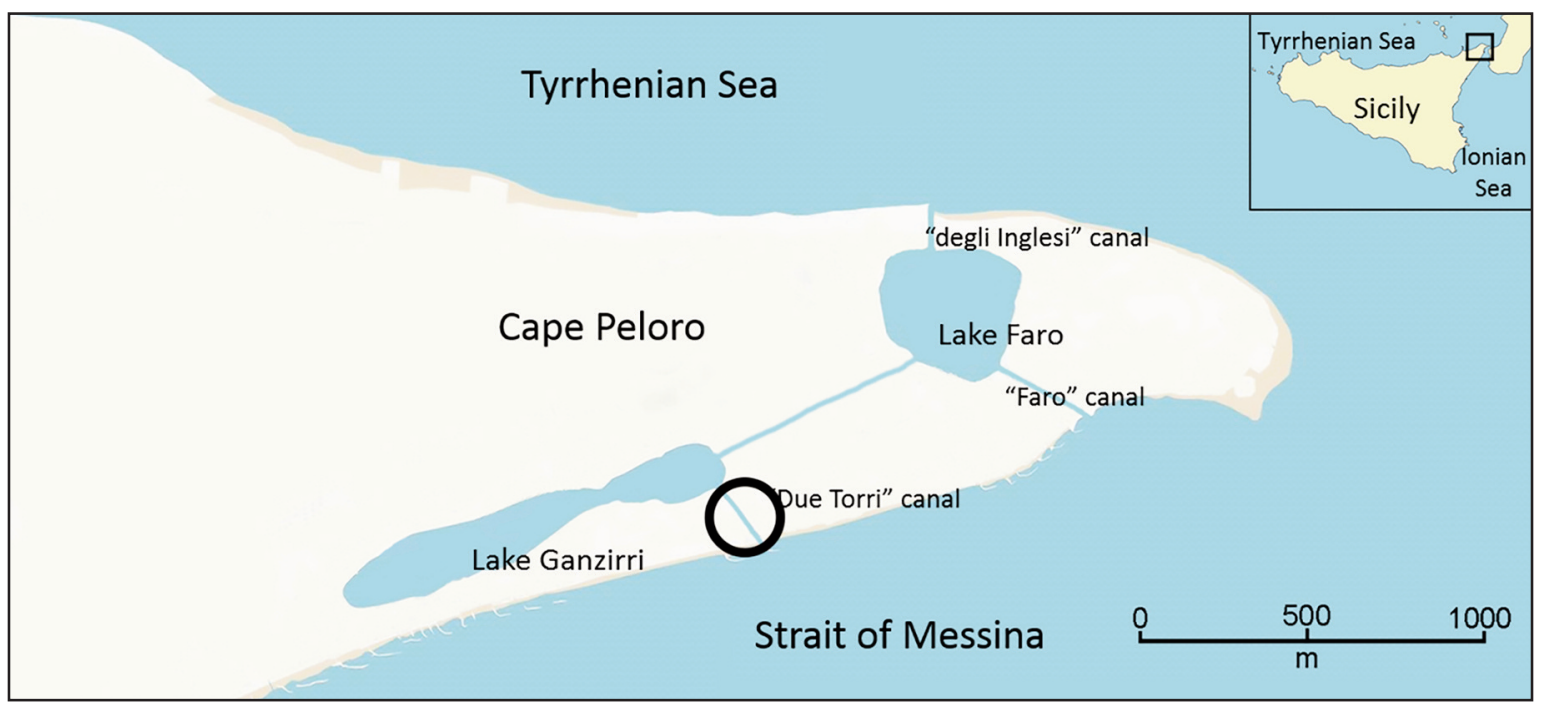

Figure 1. The Cape Peloro Lagoon. The circle indicates the sampling site, inside the "Due Torri" canal. 


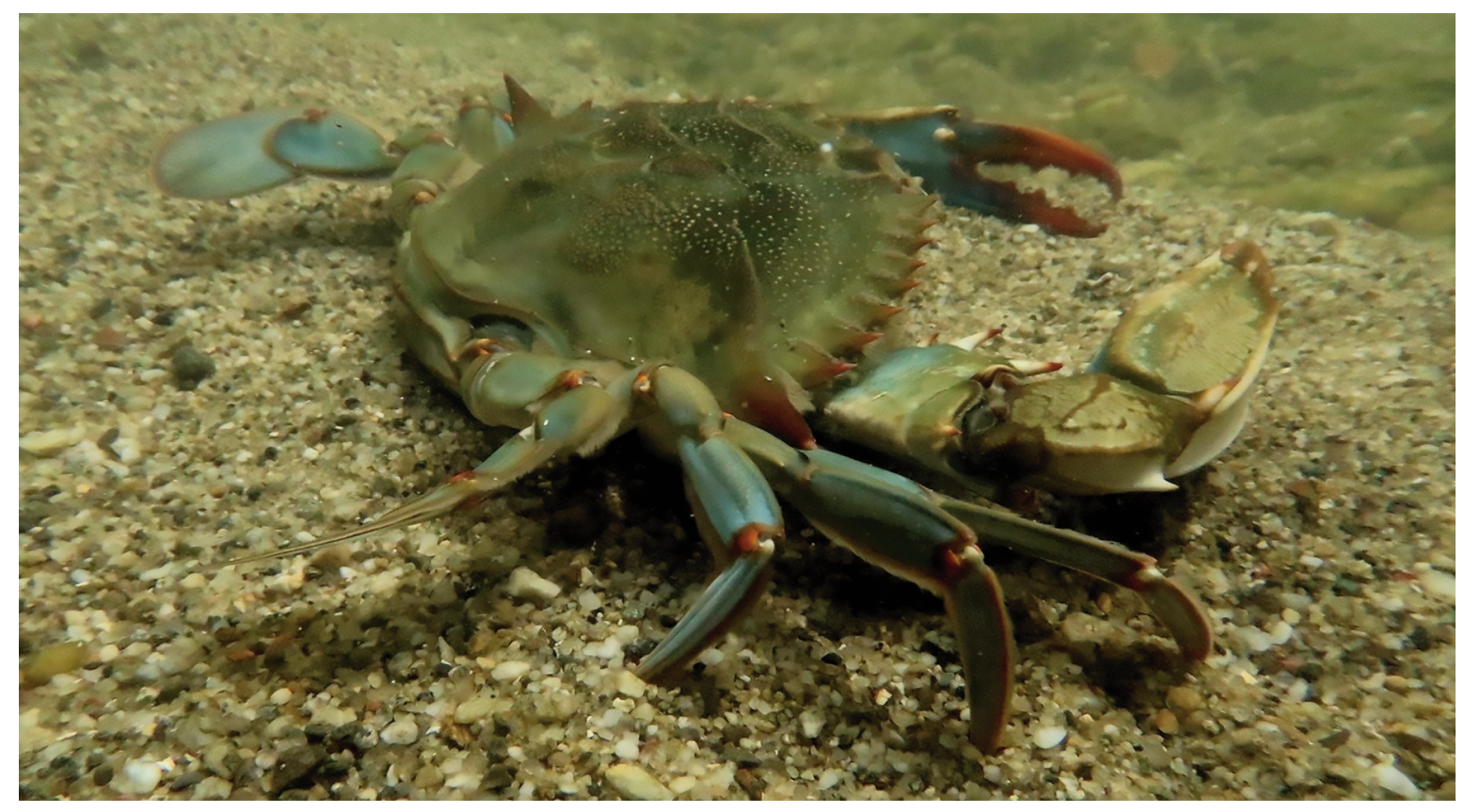

Fig. 2. In vivo photo of the described specimen, the American blue crab Callinectes sapidus.

\begin{tabular}{|l|l|}
\hline Carapace Length CL & $74.8 \mathrm{~mm}$ \\
\hline Carapace Width CW & $184.0 \mathrm{~mm}$ \\
\hline Lateral Spine Length LSL & $25.7 \mathrm{~mm}$ \\
\hline Front Margin FM & $28.4 \mathrm{~mm}$ \\
\hline Hand Length HL & $73.4 \mathrm{~mm}$ \\
\hline Lateral Posterior Margin LPM & $78.0 \mathrm{~mm}$ \\
\hline Lateral Anterior Margin LAM & $75.4 \mathrm{~mm}$ \\
\hline Orbit Width OW & $19.2 \mathrm{~mm}$ \\
\hline Abdomen Posterior Width APW & $57.8 \mathrm{~mm}$ \\
\hline Abdomen Width AW & $57.2 \mathrm{~mm}$ \\
\hline Abdomen Length AL & $54.5 \mathrm{~mm}$ \\
\hline Total Abdomen Length TAL & $72.3 \mathrm{~mm}$ \\
\hline
\end{tabular}

Table 1. Morphometric data concerning the $C$. sapidus specimen. to $C$. sapidus. Such specimens, initially held in the local aquarium collection, are now awaiting inventory at the "Museo della Fauna", Messina University. The present record is thus the second one from the Strait of Messina, almost half a century after Cavaliere \& Berdar (1975), and the third one ascertained from Sicilian waters, after Insacco \& Zava (2017). None of these records may be considered a prove of $C$. sapidus settlement, but the possibility that C. sapidus may settle in Lake Ganzirri should be carefully evaluated. This highly invasive euryhaline species, in fact, might take advantage by the absence of a competitive native fauna (Bottari et al., 2005). Fishing, furthermore, is forbidden in the Peloro Lagoon Natural Reserve, so that the recent suggestion to mitigate the $C$. sapidus impact by promoting its value as a fishery resource (Mancinelli et al., 2017), is currently unthinkable.

A conservation strategy involving selective removal of pioneer specimens, in our advise, should be thus timely envisaged.

\section{ACKNOWLEDGENENTS}

This research was sponsored by the 'Città Metropolitana di Messina' the official management body 
of the reserve (permission no. 557/VIII DIR, 12.03.2014). Facilities were provided by the mussel farm FARAU s.r.l.

\section{REFERENCES}

Bottari A., Bottari C., Carveni P., Giacobbe S. \& Spano' N., 2005. Genesis and geomorphologic and ecological evolution of the Ganzirri salt marsh (Messina, Italy). Quaternary International, 140-141: 150-158.

Cavaliere A. \& Berdar A., 1975. Presenza di Callinectes sapidus Rathbun (Decapoda, Brachyura) nello Stretto di Messina. Bollettino di Pesca, Piscicoltura e Idrobiologia, 30: 315-322.

Franceschini G., Andaloro F. \& Diviacco G., 1993. La macrofauna dei fondi strascicabili della Sicilia orientale. Il Naturalista siciliano, 17: 311-324.

Galil B., Froglia C. \& Noel P.Y., 2008. Atlas of Exotic Species in the Mediterranean. https://www.ciesm.org/ atlas/appendix 2.html (accessed 10 October February 2019).

Galil B.S., Clark P.F. \& Carlton J.T., 2011. In the Wrong Place - Alien Marine Crustaceans: Distribution, Biology and Impacts. Invading Nature - Springer Series in Invasion Ecology, 6. (C) Springer Science+Business Media B.V.

Garcia L., Pinya S., Colomar V., París T., Puig M., Rebassa M. \& Mayol J., 2018. The first recorded occurrences of the invasive crab Callinectes sapidus Rathbun, 1896 (Crustacea: Decapoda: Portunidae) in coastal lagoons of the Balearic Islands (Spain). BioInvasions Records 7: 191-196. https://doi.org/ 10.3391/bir.2018.7.2.12
Karachle P.K., 2013. Callinectes sapidus Rathbun, 1896: an established delicacy in Corfu Island. Mediterranean Marine Science, 14: 476.

Insacco G. \& Zava B., 2017. First record of the Blue Crab Callinectes sapidus in Sicily. Mediterranean Marine Science, 18: 179-201.

Mancinelli G., Carrozzo L., Costantini M.L., Rossi L., Marini G. \& Pinna M., 2013. Occurrence of the Atlantic blue crab Callinectes sapidus Rathbun, 1896 in two Mediterranean coastal habitats: Temporary visitor or permanent resident? Estuarine, Coastal and Shelf Science, 135: 46-56. https://doi.org/10.1016/j. ecss.2013.06.008

Nehring S., 2011. Invasion history and success of the American blue crab Callinectes sapidus in European and adjacent waters. In: Galil B.S., Clark P.F. \& Carlton J.T. (Eds.), In the Wrong Place - Alien Marine Crustaceans: Distribution, Biology and Impacts. Springer, Netherlands: pp. 607-624. https://doi.org/ 10.1007/978-94-007-0591-3_21

Piras P., Esposito G. \& Meloni D., 2019. On the occurrence of the blue crab Callinectes sapidus (Rathbun, 1896) in Sardinian coastal habitats (Italy): a present threat or a future resource for the regional fishery sector? BioInvasions Records 8: 134-141. https://doi. org/10.3391/bir.2019.8.1.15

Williams A.B., 1974. The swimming crabs of the Genus Callinectes (Decapoda: Portunidae). Fishery Bulletin, 72: 685-798.

Zenetos A., Cinar M.E., Pancucci-Papadopoulou M.A., Harmelin J.G., Furnari G., Andaloro F., Belou N., Streftaris N. \& Zibrowius H., 2005. Annotated list of marine alien species in the Mediterranean with records of the worst invasive species. Mediterranean Marine Science, 6: 63-118. 